\title{
POTENSI TIGA ISOLAT BAKTERI INDIGEN DARI KABUPATEN SIAK PROVINSI RIAU DALAM MENDEGRADASI NAFTALENA
}

\author{
R. Novianty ${ }^{1 *}$, B. Antika ${ }^{1}$, Saryono $^{1}$, A. Awaluddin ${ }^{1}$, N. W. Pratiwi ${ }^{2}$ \\ ${ }^{1}$ Program S1 Kimia FMIPA-Universitas Riau \\ ${ }^{2}$ Program Studi S1 Biologi FMIPA-Universitas Riau \\ *Email : rirynnovianty@lecturer.unri.ac.id
}

\begin{abstract}
ABSTRAK
Naftalena merupakan kelompok Polycyclic Aromatic Hydrocarbons (PAHs) yang bila berada di lingkungan bersifat karsinogenik. Tujuan dari penelitian ini adalah mengetahui respon pertumbuhan dan menguji efektifitas tiga isolat bakteri indigen dari kawasan Badan Operasi Bersama PT. Siak Bumi Pusako-Pertamina Hulu (BOB BSP-PHE) dalam mendegradasi naftalena. Tiga isolat tersebut diuji dalam Media Minimal (MM) cair yang mengandung naftalena dengan konsentrasi akhir $0,2 \mathrm{mM}$ dan diikubasi selama 7 hari. Optical Density (OD) dan kemampuan degradasi dianalisis menggunakan spektrofotometer UV-Vis. Hasil penelitian menunjukkan bahwa Pseudomonas sp. LBKURCC149 mampu tumbuh dalam media yang mengandung naftalena. Naftalena digunakan sebagai satu-satunya sumber karbon dan mampu mendegradasi naftalena sebesar 21,98\%.
\end{abstract}

Kata Kunci: biodegradasi, indigen, naftalena, Pseudomonas sp.

\section{ABSTRACT}

Naphthalene is a group of Polycyclic Aromatic Hydrocarbons (PAHs) which is carcinogenic when presents in the environment. The purpose of this study was to determine the growth response and test the effectiveness of three isolates of indigen bacteria from the Joint Operation Agency area of PT. Siak Bumi Pusako-Pertamina Hulu (BOB BSP-PHE) in degrading naphthalene. The three isolates were tested in a Minimum Media (MM) liquid containing naphthalene with a final concentration of $0.2 \mathrm{mM}$ and was incubated for 7 days. Optical Density (OD) and the degradation ability were analyzed using a UV-Vis spectrophotometer. The results showed that Pseudomonas sp. LBKURCC149 was able to grow in media containing naphthalene. Naphthalene is used as the only source of carbon and is able to degrade naphthalene by $21.98 \%$.

Keywords: biodegradation, indigenous, naphthalene, Pseudomonas sp.

\section{PENDAHULUAN}

Indonesia merupakan negara yang kaya akan sumber daya alam berupa minyak bumi khususnya di Provinsi Riau. Salah satu daerah penghasil minyak bumi terbanyak di Riau adalah kabupaten Siak. Mu'in (2010) menyatakan bahwa produk minyak bumi banyak dijumpai dalam bentuk bahan bakar dan bahan baku industri petrokimia seperti pelumas, lilin, dan plastik. Menurut Sulistyono dkk., (2012) selain kegunaan tersebut, minyak bumi juga dapat menyebabkan pencemaran lingkungan yang berdampak pada kerusakan ekosistem dan terganggunya kesehatan manusia. Pencemaran lingkungan akibat minyak bumi dapat terjadi secara alamiah seperti rembesan minyak bumi, maupun dari berbagai aktivitas seperti penyimpanan dan pengolahan minyak bumi.

Minyak bumi tersusun dari beberapa komponen yaitu senyawa hidrokarbon dan nonhidrokarbon. Salah satu komponen hidrokarbon terbesar minyak bumi adalah Polycyclic Aromatic Hydrocarbons (PAHs) sebanyak 25\% (Van Hamme dkk., 2003). Menurut Al-Hawash dkk., (2018) secara umum semakin tinggi berat molekul PAHs, maka sifatnya semakin hidrofobik, mengakibatkan PAHs semakin stabil dan keberadaanya di alam tersebar luas tanpa ada pengurangan konsentrasi. Berdasarkan PP No 41 tahun 1999, dijelaskan bahwa ambang batas PAHs yang diizinkan dalam lingkungan adalah 230 $\mu \mathrm{g} / \mathrm{m}^{3}$ atau setara dengan $0,23 \mu \mathrm{g} / \mathrm{kg}$. Keberadaan senyawa PAHs dalam tanah yang melebihi ambang batas akan mengancam 
kehidupan organisme tanah, karena dapat menyebabkan efek mutagenik dan karsinogenik.

Menurut Siota dkk., (2008) salah satu kelompok dari PAHs adalah naftalena yang merupakan kelompok PAHs paling sederhana yang terdiri dari dua cincin benzene dengan berat molekul rendah .Naftalena termasuk salah satu kelompok senyawa PAHs dan salah satu dari 16 PAHs yang diklasifikasikan sebagai polutan prioritas yang sering ditemukan di alam oleh Environmental Protection Agency (EPA) Amerika Serikat (Raissa dkk., 2012). Naftalena telah banyak digunakan sebagai model dalam studi bioremediasi PAHs karena strukturnya yang sederhana dan bersifat mudah larut dibandingkan dengan senyawa PAHs lainnya. Senyawa tersebut juga termasuk salah satu kelompok senyawa PAHs dominan yang terkandung dalam minyak bumi dan batu bara (Farini dkk., 2017). Hidrokarbon aromatik bisiklik ini dan turunannya dianggap sebagai beberapa senyawa yang paling berbahaya dalam fraksi minyak (Raissa dkk., 2012).

Menurut Wijayaratih (2001) di alam naftalena dijumpai pada minyak bumi, batu bara dan industri pengawetan kayu. Naftalena dapat menyebabkan kontaminasi di alam yang sering berasal dari pembuangan limbah minyak bumi dan tumpahan minyak bumi. Senyawa tersebut pada kadar tertentu dapat menghambat respirasi pada mitokondria sehingga mengakibatkan terhambatnya konsumsi oksigen pada beberapa organisme. Keracunan naftalena dapat menyebabkan anemia hemolitik dan nefrotoksisitas (Wijayaratih, 2001).

Banyak cara yang dapat digunakan untuk menanggulangi pencemaran akibat naftalena, salah satunya dengan melibatkan agen biologis yakni biodegradasi. Biodegradasi merupakan penguraian atau perombakan senyawa organik dengan memanfaatkan aktivitas mikroorganisme (Yudono dkk., 2013). Mikroba yang dapat digunakan salah satunya yakni mikroba indigen yaitu Pseudomonas sp. LBKURCC148, LBKURCC149 dan LBKURCC150 yang merupakan biota lokal yang berasal dari lingkungan yang tercemar minyak bumi di kawasan Badan Operasi Bersama PT. Siak Bumi Pusako-Pertamina Hulu (BOB BSPPHE). Mikroba indigen tersebut bersifat petrofilik yaitu memiliki kemampuan mendegradasi senyawa hidrokarbon untuk keperluan metabolisme dan perkembangbiakannya, serta mikroba ini merupakan mikroba pribumi sehingga sudah teradaptasi dengan berbagai faktor lingkungan di habitat asalnya (Munawar dkk., 2008). Oleh karena itu perlu dilakukan penelitian mengenai potensi isolat bakteri indigen tersebut dalam mendegradasi senyawa hidrokarbon kompleks khususnya naftalena.

\section{BAHAN DAN METODE}

\section{Peralatan}

Alat yang digunakan dalam penelitian ini adalah spektrofotometer UV-Vis (Genesys 10S UV-Vis v4.002 2L9N175013), Autoclaf All America model 1925/KY-23D, Oven (Fisher Scientific Model 655F), waterbath, inkubator (Heraeus Instrument D6450), blue tip, vortex mixer Genie $2^{\mathrm{TM}}$, Orbital shaker (Daihan Labtech CO., LTD), Laminar Air Flow Cabinet (LAFC), HPLC (Shimadzu LC solution seri UFLC, Kyoto, Japan), sentrifugasi, corong pisah, jarum ose, timbangan analitik (Mettler $A E$ 200), dan alat-alat standar laboratorium lainnya sesuai prosedur kerja.

\section{Bahan}

Bahan yang digunakan dalam penelitian ini adalah isolat Pseudomonas, sp. LBKURCC148, LBKURCC149 dan LBKURCC150 koleksi Laboratorium Riset Enzim, Fermentasi dan Biomolekuler, Jurusan Kimia FMIPA, Universitas Riau, media Nutrient Agar (NA) (Merck Cat. No. 1.05450), media Nutrient Broth (NB) (Merck Cat. No. 1.06649), Media Minimal (MM) yang terdiri dari: $\quad\left(\mathrm{NH}_{4}\right)_{2} \mathrm{SO}_{4}, \quad \mathrm{~K}_{2} \mathrm{HPO}_{4}, \quad \mathrm{MgSO}_{4} .7 \mathrm{H}_{2} \mathrm{O}$, $\mathrm{FeSO}_{4} \cdot 7 \mathrm{H}_{2} \mathrm{O}$, akua DM, 0,02\% tween 80 dan pH 7, naftalena (Merck), heksana, aseton, $\mathrm{NaCl}, \mathrm{NaOH}$, spiritus, alumunium foil dan alkohol antiseptik $70 \%$.

\section{Cara Kerja \\ Peremajaan masing-masing isolat bakteri pada media Nutrient Agar (NA)}

Isolat bakteri diremajakan pada media NA (Nutrient Agar). Bahan-bahan media NA adalah nutrient agar 20 gram dan akuades $1000 \mathrm{~mL}$. Nutrient agar dilarutkan dengan akuades dengan cara dipanaskan hingga homogen. Kemudian disterilisasi dalam autoklaf dengan suhu $121^{\circ} \mathrm{C}$ dengan tekanan 15 psi. Setelah autoklaf, media dituang ke 
masing-masing tabung reaksi sebanyak $\pm 5 \mathrm{~mL}$ dan dimiringkan. Selanjutnya media dibiarkan selama 1-2 hari. Bila tidak ada kontaminasi, media dapat digunakan.

Isolat bakteri diambil dari biakan murni menggunakan jarum ose. Penggoresan ose dilakukan sedemikian rupa, sehingga ujung ose hanya menyentuh diatas permukaan media. Isolat bakteri yang sudah diambil dengan jarum ose diinokulasi ke atas media NA miring. Media diinkubasi selama 1 hari pada suhu ruang.

\section{Pembuatan Starter masing-masing isolat bakteri pada media Nutrient Broth (NB) \\ Media NB (Nutrient Broth) dibuat} dengan prosedur sebagai berikut: Nutrient Broth (NB) 8 gram dan akuades $1000 \mathrm{~mL}$. Nutrient Broth (NB) dilarutkan dengan akuades dengan cara dipanaskan hingga homogen. Kemudian disterilisasi dalam autoklaf dengan suhu $121^{\circ} \mathrm{C}$ dengan tekanan 15 psi. Setelah autoklaf, media diinkubasi selama 24 jam pada suhu ruang. Bila tidak ada kontaminasi maka media dapat digunakan.

Sebanyak 1-2 ose masing-masing isolat bakteri diinokulasikan ke dalam $100 \mathrm{~mL}$ media NB dalam erlenmeyer $250 \mathrm{~mL}$. Inokulum diinkubasi selama 24 jam di dalam inkubator. Kemudian dilakukan pengukuran Optical Density (OD) pada inokulum bakteri. Martins dkk., (2011) mengutarakan pada pengukuran $\mathrm{OD}_{600 \mathrm{~nm}} \sim 0,1$ setara $10^{7} \mathrm{CFU} / \mathrm{mL}$ menggunakan spektrofotometer pada panjang gelombang $600 \mathrm{~nm}$, bertujuan untuk mengetahui perkiraan jumlah sel dalam inokulum. Pada penelitian ini digunakan OD 0,5 . Jika absorbansi diatas 0,5 maka perlu ditambahkan air salin ( $\mathrm{NaCl}$ 0,8\%) untuk menentukan masing-masing inokulum yang akan dimasukkan ke media uji memiliki OD (jumlah sel) yang relatif sama.

\section{Biodegradasi Naftalena \\ Pembuatan larutan stok naftalena}

Larutan stok naftalena $10 \mathrm{mM}$ dibuat dengan melarutkan $0,128 \mathrm{~g}$ naftalena dalam 50 $\mathrm{mL}$ aseton, kemudian dimasukan ke dalam labu takar $100 \mathrm{~mL}$ ditambahkan aseton sampai tanda batas dan dihomogenkan.

\section{Pembuatan Minimal Medium (MM)}

MM digunakan untuk uji degradasi naftalena oleh isolat bakteri. MM dibuat dengan melarutkan $2 \mathrm{~g}\left(\mathrm{NH}_{4}\right)_{2} \mathrm{SO}_{4}, 1 \mathrm{~g}$ $\mathrm{K}_{2} \mathrm{HPO}_{4}, 1 \mathrm{~g} \mathrm{KH}_{2} \mathrm{PO}_{4}, 0,2 \mathrm{~g} \mathrm{MgSO}_{4} .7 \mathrm{H}_{2} \mathrm{O}$, $0,01 \mathrm{~g} \mathrm{FeSO}_{4} .7 \mathrm{H}_{2} \mathrm{O}, 0.02 \%$ tween 80 dan $\mathrm{pH} 7$ ke dalam $1000 \mathrm{~mL}$ akuades. Media disterilkan dalam autoklaf dengan suhu $121^{\circ} \mathrm{C}$ tekanan 15 psi selama 15 menit, setelah MM dingin larutan naftalena ditambahkan dalam MM dengan konsentrasi akhir 0,2 mM. Kemudian media diinkubasi selama 1 hari, bila tidak ada kontaminasi maka media dapat digunakan.

\section{Uji biodegradasi naftalena dalam MM cair tanpa glukosa}

Uji biodegradasi dilakukan dengan menggunakan $30 \mathrm{~mL}$ MM steril yang telah ditambahkan naftalena $0,2 \mathrm{mM}$ sebagai sumber karbon dan energi. Selanjutnya setiap isolat bakteri sebanyak 5\% v/v dari suspensi sel $\left(\mathrm{OD}_{610 \mathrm{~nm}}=0,5\right)$ diinokulasikan ke dalam media dalam erlenmeyer $100 \mathrm{~mL}$. Eksperimen ini dilakukan secara triplo. Uji biodegradasi naftalena diinkubasi selama 7 hari pada rotary shaker dengan kecepatan $150 \mathrm{rpm}$ pada suhu ruang. Masing-masing inokulum dimonitor pada hari ke 0, 1, 3, 5 dan 7 dengan mengukur pertumbuhan sel melalui Optical Density (OD) pada panjang gelombang $600 \mathrm{~nm}$ dan $\mathrm{pH}$ menggunakan $\mathrm{pH}$ meter.

Panjang gelombang optimum naftalena ditentukan terlebih dahulu menggunakan spektrofotometer UV-Vis. Konsentrasinya dihitung menggunakan kurva standar naftalena dengan larutan blanko heksana. Sebelum konsentrasi sisa naftalena diukur, naftalena terlebih dahulu diekstraksi dengan menambahkan $30 \mathrm{~mL}$ heksana pada sampel, selanjutnya disentrifugasi dengan kecepatan $1200 \mathrm{rpm}$ selama 5 menit untuk memisahkan fase organik dan fase air. Kemudian $1 \mathrm{~mL}$ larutan pada fase organik diambil dan diukur absorbansinya diukur pada hari ke $0,1,3,5$ dan 7 inkubasi menggunakan spektrofotometer UV-Vis. Sebagai kontrol digunakan MM dengan naftalena (tanpa isolat bakteri) (Pawar dkk., 2013). Persentase biodegradasi naftalena dapat dihitung melalui persaman berikut ini.

$$
\% \text { Degradasi }=\frac{\text { Konsentrasi pada Kontrol-Konsentrasi pada Inokulum }}{\text { Konsentrasi pada Kontrol }} \times 100 \%
$$

(Trikurniadewi, N. 2015). 
Naftalena pada isolat dengan persentase biodegradasi tertinggi dianalisis menggunakan HPLC.

\section{HASIL DAN PEMBAHASAN}

\section{Parameter Optical Density (OD) selama proses degradasi}

Pertumbuhan masing-masing isolat dalam MM cair dengan penambahan naftalena
0,2 $\mathrm{mM}$ diamati melalui parameter OD selama waktu inkubasi. Pertumbuhan isolat dilihat berdasarkan kekeruhan larutan (Vanishree dkk., 2014). Masing-masing isolat menunjukkan respon pertumbuhan positif pada MM cair dengan adanya naftalena sebagai sumber karbon utamanya.

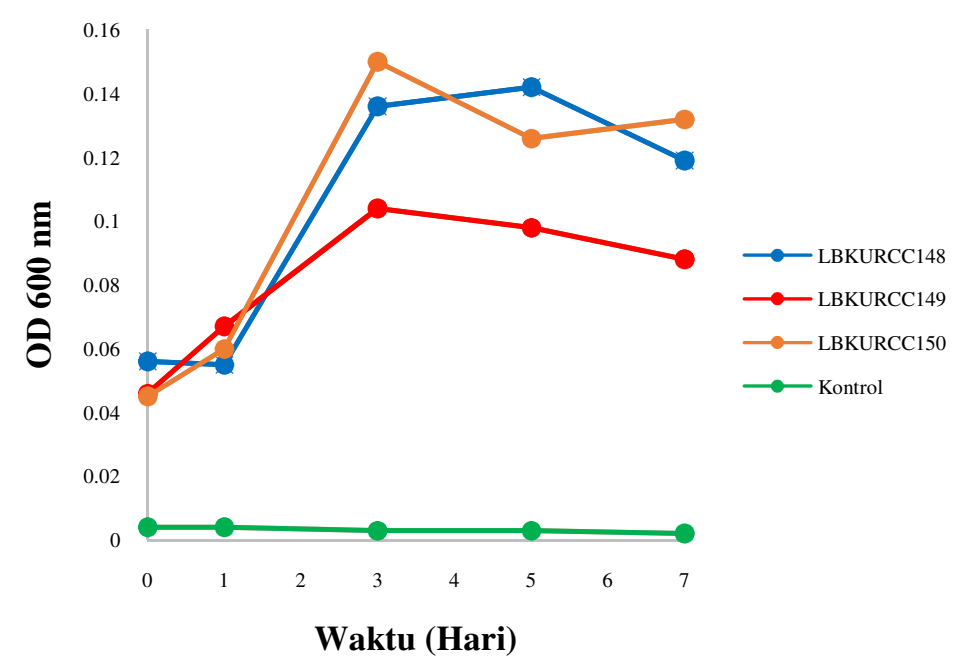

Gambar 1. OD Isolat dalam MM Cair selama Waktu Inkubasi

Masing-masing isolat bakteri yang digunakan pada penelitian ini menunjukkan respon pertumbuhan positif pada MM cair dengan adanya naftalena sebagai sumber karbon utamanya. Pada Gambar 1 terlihat bahwa fase eksponensial pada Pseudomonas, sp. LBKURCC148, LBKURCC149 dan LBKURCC150 terjadi hingga hari ketiga waktu inkubasi. Selanjutnya masing-masing isolat mengalami fase stasioner hingga hari ketujuh waktu inkubasi. Hal ini didukung dengan hasil analisis menggunakan uji Duncan yang dapat dilihat pada Tabel 1 yang menunjukkan bahwa pada waktu inkubasi hari ketiga pada umumnya terjadi perbedaan secara signifikan yang dibandingkan dengan waktu inkubasi 0 dan 1 hari. Selanjutnya masingmasing isolat mengalami fase stasioner hingga hari ketujuh waktu inkubasi. Hasil uji Duncan OD bakteri dapat dilihat pada Tabel 1 berikut ini.

Tabel 1. Hasil Uji Duncan OD

\begin{tabular}{ccccc}
\hline $\begin{array}{c}\text { Waktu } \\
\text { inkubasi } \\
\text { (hari) }\end{array}$ & $\begin{array}{c}\text { Pseudomonas sp. } \\
\text { LBKURCC148 }\end{array}$ & $\begin{array}{c}\text { Pseudomonas sp. } \\
\text { LBKURCC149 }\end{array}$ & $\begin{array}{c}\text { Pseudomonas sp. } \\
\text { LBKURCC150 }\end{array}$ & Kontrol \\
\hline 0 & $0,056 \pm 0,010^{\mathrm{a}}$ & $0,046 \pm 0,006^{\mathrm{a}}$ & $0,045 \pm 0,004^{\mathrm{a}}$ & $0,004 \pm 0,003^{\mathrm{a}}$ \\
\hline 1 & $0.055 \pm 0,020^{\mathrm{a}}$ & $0,067 \pm 0,006^{\mathrm{a}, \mathrm{b}}$ & $0,060 \pm 0,010^{\mathrm{a}}$ & $0,004 \pm 0,003^{\mathrm{a}}$ \\
\hline 3 & $0.136 \pm 0,070^{\mathrm{a}, \mathrm{b}}$ & $0,104 \pm 0,025^{\mathrm{c}}$ & $0,150 \pm 0,050^{\mathrm{b}}$ & $0,003 \pm 0,002^{\mathrm{a}}$ \\
\hline 5 & $0.142 \pm 0,028^{\mathrm{b}}$ & $0,098 \pm 0,028^{\mathrm{b}, \mathrm{c}}$ & $0,126 \pm 0,022^{\mathrm{b}}$ & $0,003 \pm 0,002^{\mathrm{a}}$ \\
\hline 7 & $0.119 \pm 0,054^{\mathrm{a},}$ & $0,088 \pm 0,012^{\mathrm{b}}$ & $0,132 \pm 0,030^{\mathrm{b}}$ & $0,002 \pm 0,000^{\mathrm{a}}$ \\
\hline
\end{tabular}


Nilai Optical Density (OD) isolat bakteri diuji menggunakan uji Duncan (Tabel 1) dengan signifikansi $(\mathrm{P}<0,05)$. Berdasarkan hasil uji Duncan terlihat bahwa pada media tanpa glukosa peningkatan OD pada masing-masing isolat tidak berbeda nyata. Kontrol berbeda nyata dengan semua isolat karena tidak diberi inokulum yang artinya tidak ada yang mendegradasi substrat sehingga nilai OD tidak meningkat. Tidak adanya peningkatan OD membuktikan bahwa kontrol benar-benar steril. Pada media dengan adanya glukosa berdasarkan hasil uji Duncan terjadi perbedaan secara nyata pada masing-masing isolat dan kontrol.

\section{Parameter $\mathbf{p H}$ selama proses degradasi}

Parameter $\mathrm{pH}$ merupakan faktor penting yang berpengaruh pada aktivitas mikroorganisme dan mempengaruhi kecepatan degradasi. Penurunan $\mathrm{pH}$ pada MM cair terjadi dari 7 menjadi 6 pada masing-masing isolat. Perubahan $\mathrm{pH}$ pada media mengindikasikan adanya pertumbuhan dan metabolit yang dihasilkan mikroba. Hal ini dapat dilihat pada Gambar 2 berikut ini:

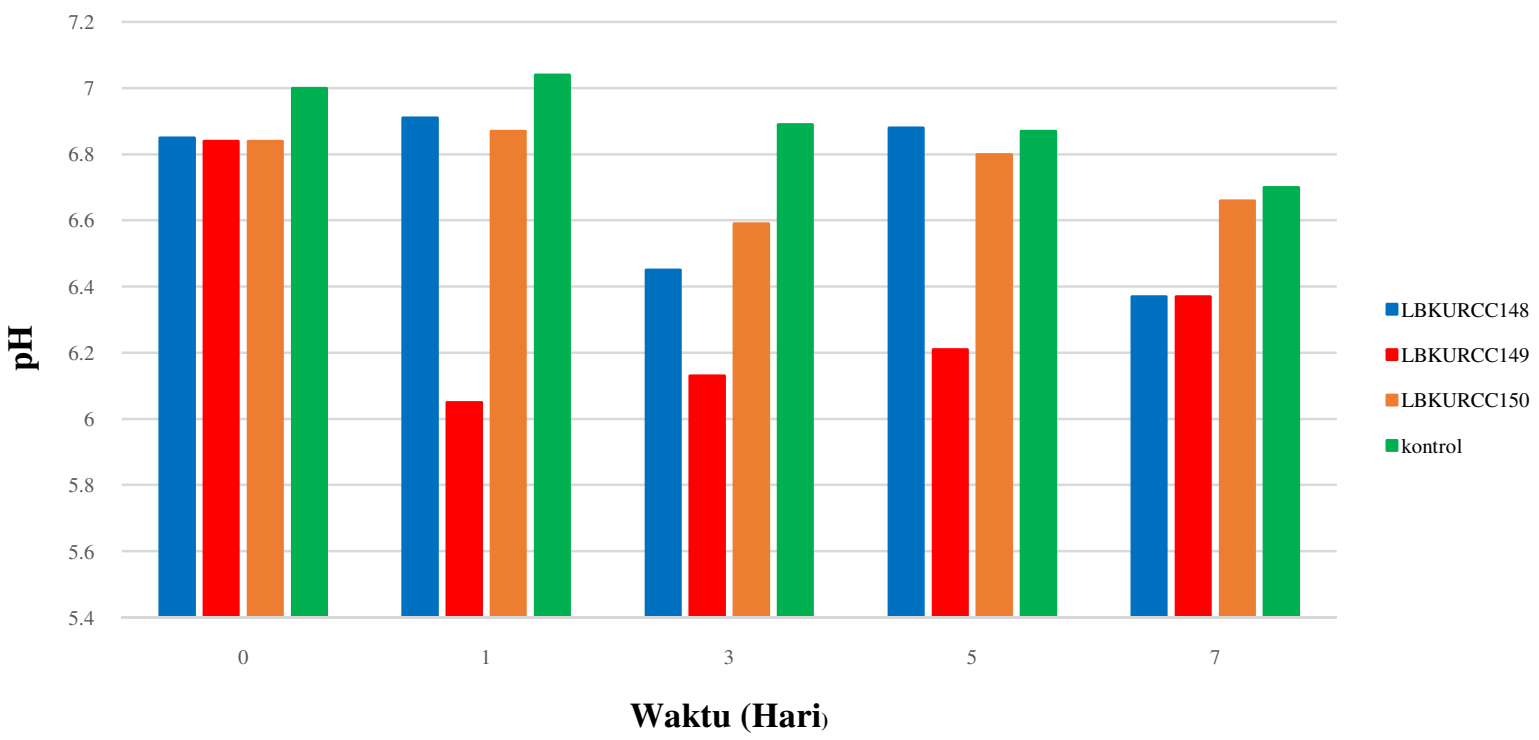

Gambar 2. pH Isolat Dalam MM Cair Selama Waktu Inkubasi

Tabel 2. Hasil Uji Duncan Ph

\begin{tabular}{ccccc}
\hline \multirow{2}{*}{$\begin{array}{c}\text { Waktu } \\
\text { inkubasi } \\
\text { (hari) }\end{array}$} & $\begin{array}{c}\text { Pseudomonas sp. } \\
\text { LBKURCC148 }\end{array}$ & $\begin{array}{c}\text { Pseudomonas sp. } \\
\text { LBKURCC149 }\end{array}$ & $\begin{array}{c}\text { Pseudomonas sp. } \\
\text { LBKURCC150 }\end{array}$ & Kontrol \\
\hline 0 & $6,85 \pm 0,14^{\mathrm{a}}$ & $6,84 \pm 0,29^{\mathrm{a}}$ & $6,84 \pm 0,09^{\mathrm{a}, \mathrm{b}}$ & $7,00 \pm 0,63^{\mathrm{a}}$ \\
\hline 1 & $6,91 \pm 0,29^{\mathrm{a}}$ & $6,72 \pm 0,25^{\mathrm{a}}$ & $6,87 \pm 0,09^{\mathrm{b}}$ & $7,04 \pm 0,22^{\mathrm{a}}$ \\
\hline 3 & $6,45 \pm 0,42^{\mathrm{a}}$ & $6,79 \pm 0,19^{\mathrm{a}}$ & $6,59 \pm 0,23^{\mathrm{a}}$ & $6,89 \pm 0,52^{\mathrm{a}}$ \\
\hline 5 & $6,88 \pm 0,33^{\mathrm{a}}$ & $6,55 \pm 0,40^{\mathrm{a}}$ & $6,80 \pm 0,14^{\mathrm{a}, \mathrm{b}}$ & $6,87 \pm 0,31^{\mathrm{a}}$ \\
\hline 7 & $6,37 \pm 0,23^{\mathrm{a}}$ & $6,70 \pm 0,23^{\mathrm{a}}$ & $6,66 \pm 0,04^{\mathrm{a}, \mathrm{b}}$ & $6,70 \pm 0,03^{\mathrm{a}}$ \\
\hline
\end{tabular}

Berdasarkan uji Duncan pada Tabel 2 tampak bahwa tidak terjadi perbedaan secara nyata antara masing-masing isolat dengan kontrol.
Penurunan konsentrasi naftalena selama proses degradasi 
Kemampuan isolat bakteri dalam mendegradasi naftalena ditentukan berdasarkan jumlah konsentrasi sisa naftalena yang diukur menggunakan spektrofotometer UV-Vis pada panjang gelombang $289 \mathrm{~nm}$. Konsentrasi naftalena yang terdegradasi selama waktu inkubasi dapat ditentukan melalui kurva standar naftalena dengan larutan blanko heksana dan penurunan konsentrasi naftalena dapat dilihat pada Gambar 3 berikut.

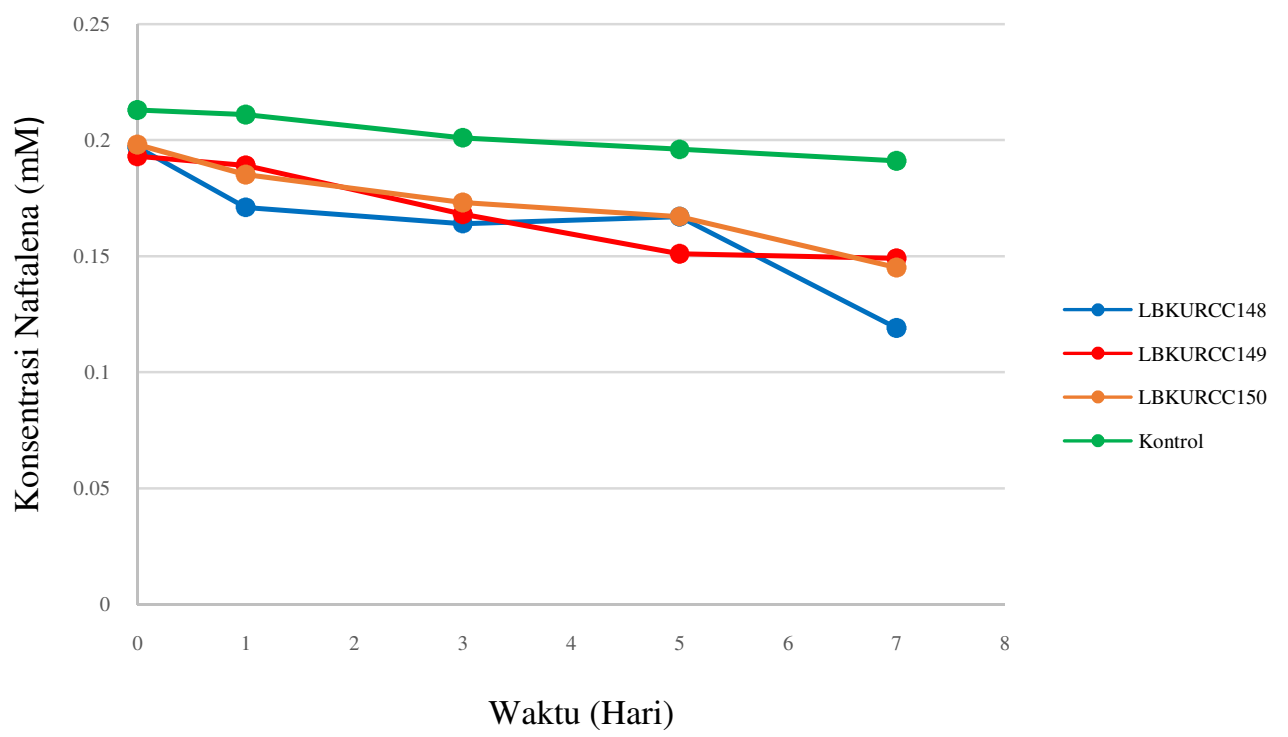

Gambar 3. Penurunan Konsentrasi Naftalena Selama Waktu Inkubasi

Pada gambar tersebut terlihat bahwa hingga hari ke tujuh waktu inkubasi konsentrasi naftalena semakin menurun. Berdasarkan hasil uji Duncan menunjukkan bahwa tidak terjadi perubahan konsentrasi secara nyata pada Pseudomonas sp. LBKURCC149 dan LBKURCC50 hingga hari ketujuh waktu inkubasi, namun pada isolat Pseudomonas sp. LBKURCC148 terjadi perubahan konsentrasi naftalena secara nyata pada hari ke tujuh waktu inkubasi. Hasil uji Duncan dapat dilihat pada Tabel 3 berikut ini.

Tabel 3. Hasil Uji Duncan Konsentrasi naftalena

\begin{tabular}{ccccc}
\hline $\begin{array}{c}\text { Waktu } \\
\text { inkubasi } \\
\text { (hari) }\end{array}$ & $\begin{array}{c}\text { Pseudomonas sp. } \\
\text { LBKURCC148 }\end{array}$ & $\begin{array}{c}\text { Pseudomonas sp. } \\
\text { LBKURCC149 }\end{array}$ & $\begin{array}{c}\text { Pseudomonas sp. } \\
\text { LBKURCC150 }\end{array}$ & Kontrol \\
\hline 0 & $0,197 \pm 0,010^{\mathrm{b}}$ & $0,193 \pm 0,038^{\mathrm{a}}$ & $0,199 \pm 0,045^{\mathrm{a}}$ & $0,213 \pm 0,019^{\mathrm{b}}$ \\
\hline 1 & $0,171 \pm 0,033^{\mathrm{b}}$ & $0,189 \pm 0,013^{\mathrm{a}}$ & $0,185 \pm 0,019^{\mathrm{a}}$ & $0,211 \pm 0,001^{\mathrm{b}}$ \\
\hline 3 & $0,164 \pm 0,024^{\mathrm{b}}$ & $0,168 \pm 0,028^{\mathrm{a}}$ & $0,173 \pm 0,049^{\mathrm{a}}$ & $0,201 \pm 0,005^{\mathrm{a}, \mathrm{b}}$ \\
\hline 5 & $0,168 \pm 0,018^{\mathrm{b}}$ & $0,151 \pm 0,022^{\mathrm{a}}$ & $0,167 \pm 0,036^{\mathrm{a}}$ & $0,195 \pm 0,000^{\mathrm{a}, \mathrm{b}}$ \\
\hline 7 & $0,119 \pm 0,021^{\mathrm{a}}$ & $0,149 \pm 0,035^{\mathrm{a}}$ & $0,146 \pm 0,047^{\mathrm{a}}$ & $0,191 \pm 0,002^{\mathrm{a}}$ \\
\hline
\end{tabular}

Konsentrasi naftalena pada akhir masa inkubasi adalah 0,119, 0,149 dan 0,145 mM. Berdasarkan data tersebut, dapat dihitung persentase degradasi naftalena sebesar 37,69\%, $21,98 \%$ dan $24,08 \%$. Hal ini menunjukkan 
bahwa masing-masing isolat ini mampu mendegradasi naftalena.

\section{SIMPULAN DAN SARAN}

\section{Simpulan}

Berdasarkan penelitian yang dilakukan dapat disimpulkan bahwa Pseudomonas sp. LBKURCC149 memiliki kemampuan mendegradasi naftalena sebesar $21,98 \%$ yang disertai dengan kenaikan OD.

\section{Saran}

Disarankan pada penelitian selanjutnya untuk menambahkan waktu inkubasi agar persentase biodegradasi meningkat.

\section{DAFTAR PUSTAKA}

Al-Hawash, A. B., Alkooranee, J. T., Zhang, X. dan Ma, F. 2018. Fungal degradation of polycyclic aromatic hydrocarbons. International Journal of Pure and Applied Bioscience. 6(2): 8-24.

Farini, N., Thontowi, A., Yetti, E., Yopi, S., 2017. Pertumbuhan bakteri laut Shewanella indica lbf-1-0076 dalam naftalena dan deteksi gen naftalena. J. Biopropal Ind. 8, 19-31.

Mu'in, R. 2010. Upaya memperpanjang pemakaian minyak bumi. Jurnal Teknik Kimia. 2(17): 9-15.

Munawar, Estuningsih, S.P., Yudono, Said, M. dan Salni. 2008. Studi penggunaan bakteri indigen petrofilik dalam proses bioremediasi hidrokarbon minyak bumi di wilayah Sumatera bagian selatan. Jurnal Kimia Lingkungan. 16 (2): 3-10.

Pawar, A. N., Ugele, S. S., More, M. G., Kokani, N. F. dan Khandelwan, S. R. 2013. Biological degradation of naphthalene: A New Era. Journal of Bioremediation and Biodegradation. 4(7): 4-5.
Raissa, K. R., Augustin, M. dan Benoit, N. M. 2012. Naphthalene biodegradation by microbial consortia isolated from soils in Ngaoundere (Cameroon). International Journal of Environmental Sciences. 3(1): 1-10.

Siota, L. F., Santos, F., Miguel, T. dan Villa, T. 2008. Biodegradation of naphthalene by Pseudomonas stutzeri in marine environments: testing cells entrapmentin calcium alginate for use in water detoxification. Bioremediation Journal. 12(4): 185-192.

Sulistyono, Suntoro dan Masykuri, M. 2012. Kajian dampak tumpahan minyak dari kegiatan operasi kilang minyak terhadap kualitas air dan tanah (studi kasus kilang minyak pusdiklat migas Cepu). Jurnal Ekosains. 4(2): 23-34.

Trikurniadewi, N. 2015. Biodegradasi naftalen dan fenantren oleh Bacillus subtilis 3KP. Skripsi. Surabaya: Universitas Airlangga.

Vanishree, M. Thatheyus, A. J. dan Ramya, D. 2014. Biodegradation of petrol using fungus Peniciliium sp. Science International. 2(1): 26-31.

Van Hamme, J. D., Singh, A. dan Ward, O. P. 2003. Recent advances in petroleum microbiology. Microbiology and Molecular Biology Reviews. 4(67): 503549.

Wijayaratih, Y. 2001. Perombakan senyawa hidrokarbon aromatis polisiklik (naftalen) pada kadar tinggi oleh Pseudomonas NY1. Jurnal Manusia dan Lingkungan. 8(3): 130-141.

Yudono, B., Estuningsih, S. P., Said, M., dan Napoleon, A. 2013. Eksplorasi Bakteria indigen Pendegradasi Limbah Minyak Bumi di Wilayah PT Pertamina UBEP Limau Muara Enim. Prosiding Semirata FMIPA Universitas Lampung. Lampung. 21 November 2013. 